\title{
INTERNATIONALIZATION OF POLISH ENTERPRISES. A COMPARATIVE ANALYSIS OF FAMILY AND NON-FAMILY BUSINESSES
}

\author{
Izabella STEINEROWSKA-STREB \\ University of Economics in Katowice, Poland; streb@ue.katowice.pl, ORCID: 0000-0001-5379-5730
}

\begin{abstract}
Purpose: The study aimed to determine whether family businesses in Poland are as involved in international activity as non-family businesses. Moreover, the intention was to identify differences in the forms of foreign expansion employed by family and non-family firms.

Design/methodology/approach: The objectives were pursued based on primary research conducted in 188 family firms and 223 non-family firms operating on the Polish market.

Findings: The analysis of the results indicates that family firms conduct business activity outside the domestic market significantly less frequently than non-family firms. The most common form of internationalization chosen by Polish family firms is export and import. Generally, these firms are not interested in joint ventures with foreign partners. Compared to non-family firms, Polish family firms establish divisions abroad significantly less frequently. However, they engage in non-equity cooperation more often than non-family firms.

Practical implications: Knowledge about the involvement of family and non-family firms in international activity and their preferred forms of internationalization can be used by business environment institutions.

Originality/value: The study results enrich the knowledge on the activity of Polish family firms on foreign markets as compared to similar activity of non-family businesses.
\end{abstract}

Keywords: family firm, non-family firm, internationalization, SME.

Category of the paper: research paper.

\section{Introduction}

Technological development and globalization processes that occurred in the global economy at the turn of the $20^{\text {th }}$ and $21^{\text {st }}$ century caused that expansion into international markets became profitable not only for large corporations, but also for smaller firms (Casillas, and Moreno-Menéndez, 2017). Therefore, in the early $21^{\text {st }}$ century, many firms that had previously focused only on the internal market began to engage in international activity (Camison, and Villar-Lopez, 2010; Lesáková, 2014). Among them there were also family firms. 
They began to perceive international expansion as an opportunity for growth that would ensure employment security for future generations (Pukall, and Calabrò, 2014).

Currently, family businesses successfully compete with non-family businesses on the international arena. However, not all family firms decide to expand their operations outside the country. Many remain in local markets (Mitter et al., 2014), concerned that foreign expansion might lead to a loss of family control over the firm. Casillas et al. (2010) argue that family businesses face two opposing forces. One urges them to grow and expand beyond their traditional markets, while the other encourages them to seek stability and pursue low risk projects in familiar markets.

The internationalization of family businesses has attracted interest of researchers over the recent years (Alayo et al., 2020; Casillas and Moreno-Menéndez, 2017). Nevertheless, to date, research has been inconclusive as to whether family businesses are more involved in international activity than non-family businesses. In general, it is argued that family involvement in business and family ownership have an impact on the internationalization of family businesses (Alayo et al., 2020; Arregle et al., 2012).

In Poland, the issue of internationalization of family businesses is under-researched (Leszczewska and Zaniewska, 2013). The question whether family businesses operating on the Polish market are as active on foreign markets as non-family businesses still remains unanswered. Studies on differences between family and non-family firms in terms of preferred expansion methods are also scarce. The survey discussed in this paper intended to fill this research gap, as it aimed to identify whether family businesses in Poland are as involved in international activity as non-family businesses. Moreover, the study sought to identify differences in foreign expansion methods chosen by family and non-family firms. The objectives of the study were pursued based on primary research.

\section{Literature review}

Enterprises are motivated to launch activity in foreign markets by the opportunity to make better use of economies of scale, access to cheaper production factors, access to know-how in foreign industrial clusters, and potential risk diversification (Pukall, and Calabrò, 2014; Steinerowska-Streb, 2014). Foreign market entry, however, requires every firm to learn a new environment (Casillas et al., 2010) and engage capital resources (Mitter et al., 2014). Thus, foreign expansion contributes to firms' uncertainty and risk (Arregle et al., 2012; LarrazaKintana et al., 2007). Not all firms are willing to take this risk. Enterprises that exercise particular caution are family firms. In principle, they do not want to lose family control over the business and are reluctant to make any decisions that could reduce it (Casillas et al., 2010). 
Low risk-taking propensity of family businesses stems from their concern for future generations. They have a particularly long-term orientation (Muñoz-Bullón et al., 2020) and seek to transfer ownership to their successors. Most often, therefore, they value tradition and are used to operating in local markets known to them (Mitter et al., 2014), where they have developed close ties with local communities (Steinerowska-Streb, 2016). Therefore, compared to non-family firms, many family-owned businesses adopt conservative strategies (Steinerowska-Streb, and Wziątek-Staśko, 2019) and are less inclined to invest in high risk projects, including foreign market expansion (Mitter et al., 2014).

Long-term orientation of family firms and the concern of the family with future generations can also have a positive impact on their internationalization (Alayo et al., 2020). They can perceive expansion beyond the internal market as an opportunity to grow and survive in a changing environment (Pukall, and Calabrò, 2014). Studies carried out in this area provide varied conclusions (Mitter et al., 2014). Some argue that the characteristics of family businesses favor their internationalization (Carr, and Bateman, 2009). Others, on the contrary, point to negative relationships in this respect (Fernández, and Nieto, 2006; Graves, and Thomas, 2004). In their study, Mitter et al. (2014) indicate that family ownership and international entrepreneurship exhibit an inverted U-shaped relationship.

This study assumes that, in Polish market conditions, the fact of being a family business has a negative impact on internationalization. Most family businesses operating on the Polish market are only approaching their first succession or are run by their first successor, and the first generation in a family business usually experience resource constraints that may hinder their foreign expansion. These limitations can be overcome by family members of the second or subsequent generation (Mitter et al., 2014). Therefore, it was considered likely that:

H1: Family businesses in Poland are less involved in international activity than non-family businesses.

To date, relatively few comparative analyses concerning the internationalization of family and non-family firms have been conducted. They generally show that the internationalization process varies in family and non-family businesses (Alayo et al., 2020) and, compared to nonfamily businesses, family businesses expand abroad later, more slowly and avoiding risk (Mitter et al., 2014). Accordingly, the characteristics of family businesses may therefore not only influence their propensity for internationalization, but they may also lead them to choose different internationalization strategies for foreign expansion compared to non-family businesses (Mitter et al., 2014).

Given that family firms mainly finance their operations from family resources (Mandl, 2008) and they do not want to lose family control of the business and are reluctant to make any decisions that might reduce it (Casillas et al., 2010), it can be assumed that family firms prefer less capital-intensive forms of expansion than non-family firms. On the other hand, taking into 
account that family firms tend to recruit employees from among family members (Steinerowska-Streb, and Bernais, 2016), who do not necessarily possess professional knowledge about internationalization strategies (Mitter et al., 2014), it can be proposed that family businesses (i) are less likely to establish their own divisions abroad than non-family firms; (ii) are more likely to pursue non-equity cooperation (license contracts, franchise agreements, management contracts, turnkey investment contracts, supply contracts) than nonfamily firms. Therefore, the study assumed that:

H2: Family firms are significantly less likely to establish divisions abroad than non-family firms.

H3: Family firms are significantly more likely to engage in non-equity cooperation than nonfamily firms.

\section{Methods}

The research hypotheses were verified and the research objectives were achieved based on primary research findings. The study was conducted as part of statutory research carried out by the Department of Entrepreneurship and Management Innovation at the University of Economics in Katowice (project title: Competitiveness of family and non-family firms comparative analysis in selected areas).

A questionnaire was prepared for the purpose of the survey, concerning the broadly defined firm competitiveness and its determinants. It consisted of closed questions, in which the type of scale was adjusted to the examined area. This paper focuses analysis only on the questions about firm internationalization, since its theme is the internationalization of family businesses as compared to non-family businesses. All the questionnaire questions concerning this research area used a nominal scale.

The subject of the study comprised family and non-family firms based in Poland. The research sample was selected by the Center for Research and Knowledge Transfer (CBiTW) from its database of enterprises. The sample was intended to include at least 380 enterprises. Ultimately, the sample size reached 411 firms. During the first half of 2020, CBiTW ran an email survey in order to gather data. 950 invitations to participate in the survey were sent out, 400 were addressed to family businesses and 550 to non-family businesses. 248 family and 229 non-family businesses responded to the invitation. After the questionnaires filled by the respondents were verified, 66 were rejected. All those questionnaires that were incomplete or did not meet the assumptions made upon selection of the research sample were eliminated from further analysis. 
Finally, 188 questionnaires from family businesses and 223 from non-family businesses were analyzed. Ownership and management criteria were used to identify family businesses as these criteria are most commonly used for this purpose (Kontinen, and Ojala, 2010; Kraśnicka, 2017). Serrano-Bedia et al. (2016, p. 498) proposed that a family firm is a firm "in which a family controls the majority of the ordinary voting shares and the family is represented in the firm's management".

Based on the size of family businesses, the systemization revealed $30.3 \%$ of micro firms, $42 \%$ of small businesses, $25 \%$ of medium-sized firms, and $2.1 \%$ of large enterprises. The group of non-family firms comprised $19.4 \%$ of micro firms, $17.9 \%$ of small businesses, 39.5 of medium-sized firms, and $23.3 \%$ of large enterprises. The classification of enterprises in terms of size was conducted according to the number of people employed in full-time positions. The threshold values were adopted from the recommendation of the European Commission (2003) on the definition of micro, small and medium-sized enterprises. According to the recommendation, a microenterprise is as an enterprise which employs no more than 9 workers. A small enterprise employs between 10 and 49 workers, while a medium-sized enterprise between 50 and 249 employees. Large enterprises are those with staff headcount of 250 or more.

The analysis of the data used descriptive statistics and the $\chi^{2}$ significance test. The statistically significant level was established for $p$ to be below 0.05. Moreover, the Bayes Factor $\mathrm{BF}_{10}$ was applied to examine the likelihood of the hypotheses. When $\mathrm{BF}_{10}$ was in the range (i) 1-3, the evidence for the hypothesis was considered to be insufficient; (ii) 3-10 -substantial; (iii) 10-30 - strong; (iii) 30-100 - very strong; (iii) over 100 - extreme (Domurat, and Białek, 2016).

\section{Results}

The analysis of the data revealed that the respondent enterprises were dominated by the firms that are not involved in international activity (67.4\%). Among the enterprises operating on foreign markets, $73.9 \%$ were non-family firms, while the remaining $26.1 \%$ were family firms. Both family and non-family firms were dominated by firms whose operations were limited to the domestic market (Figure 1). 


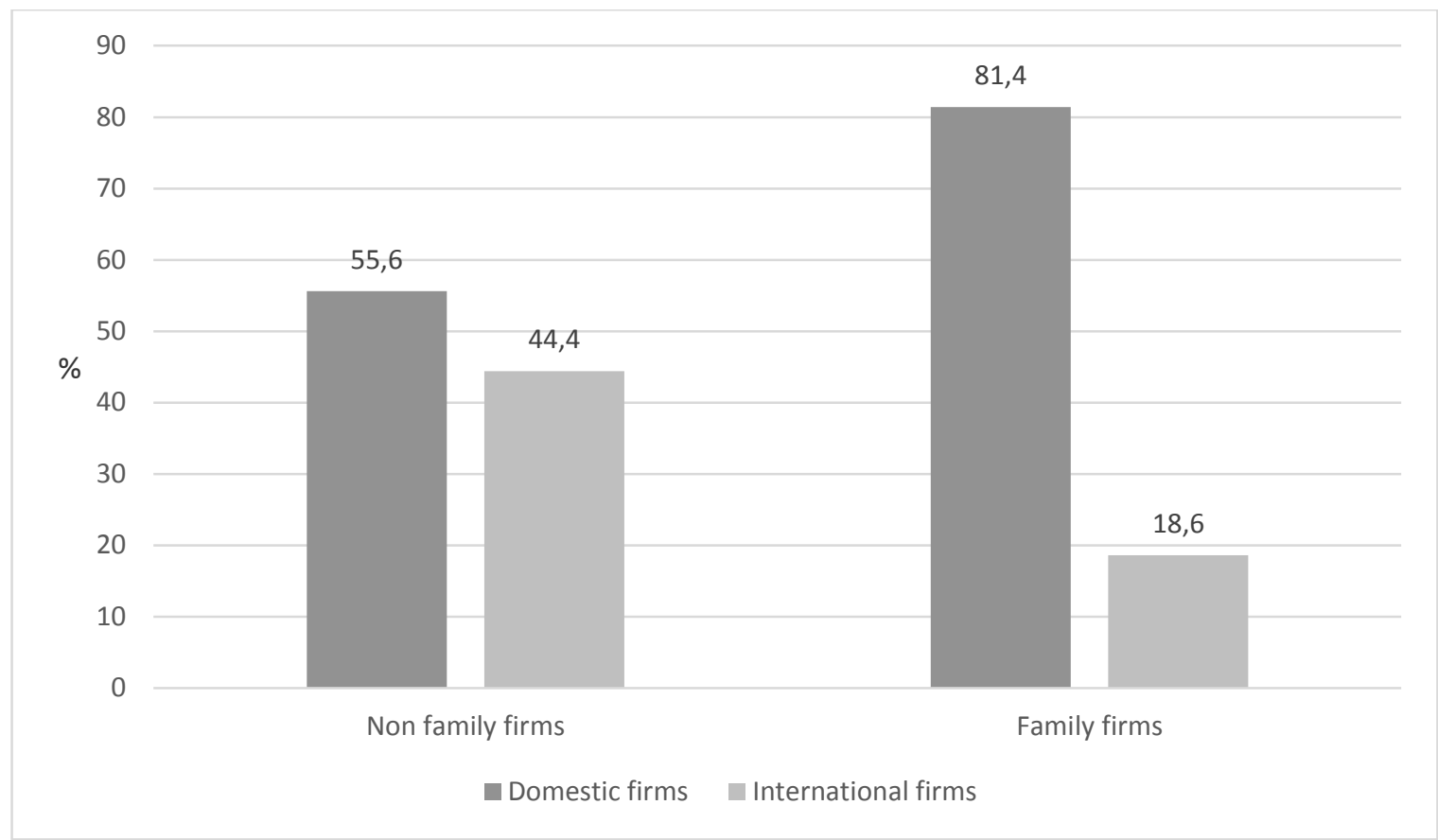

Figure 1. Involvement of family and non-family firms in international activity (\%). Source: Own elaboration.

Medium-sized enterprises dominated among family firms that operated internationally. On the other hand, large enterprises were the most numerous among non-family firms involved in international activity. Both family and non-family micro firms declared conducting international activity. Interestingly, among family firms, as many as every tenth firm (approximately) that conducted international activity was a micro firm. Respectively, micro firms constituted $9.1 \%$ of non-family firms involved in international operations (Figure 2).

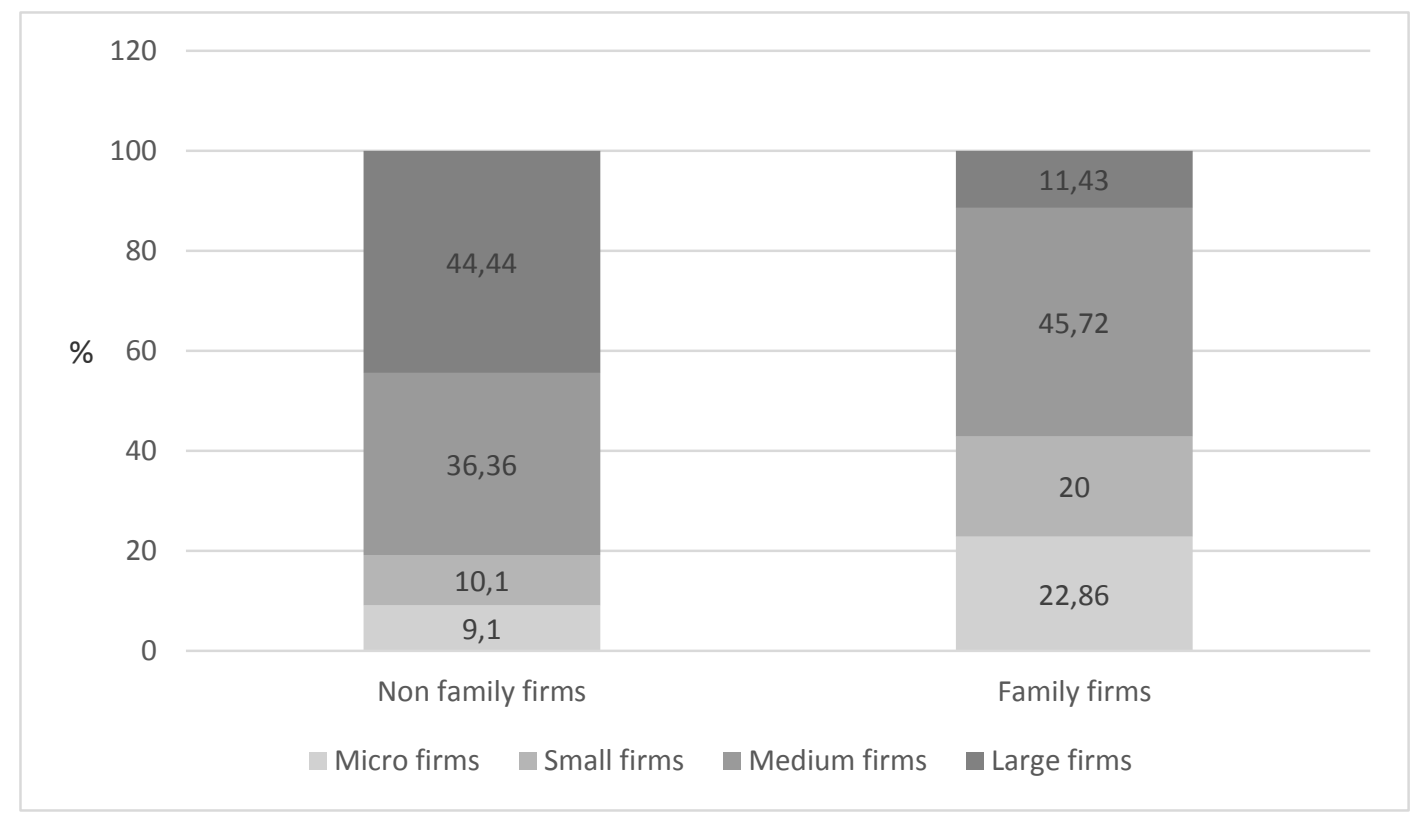

Figure 2. Family and non-family firms not involved in international activity by size (\%). Source: Own elaboration. 
The size-based composition of the respondent firms that did not conduct international operations was slightly different from that of internationalized firms. Among family firms that did not operate internationally, there were no large enterprises, whereas among non-family firms, large enterprises constituted only $6.45 \%$. Small enterprises dominated among non-internationalized family firms, while medium-sized enterprises were the most numerous group among non-family firms (Figure 3).

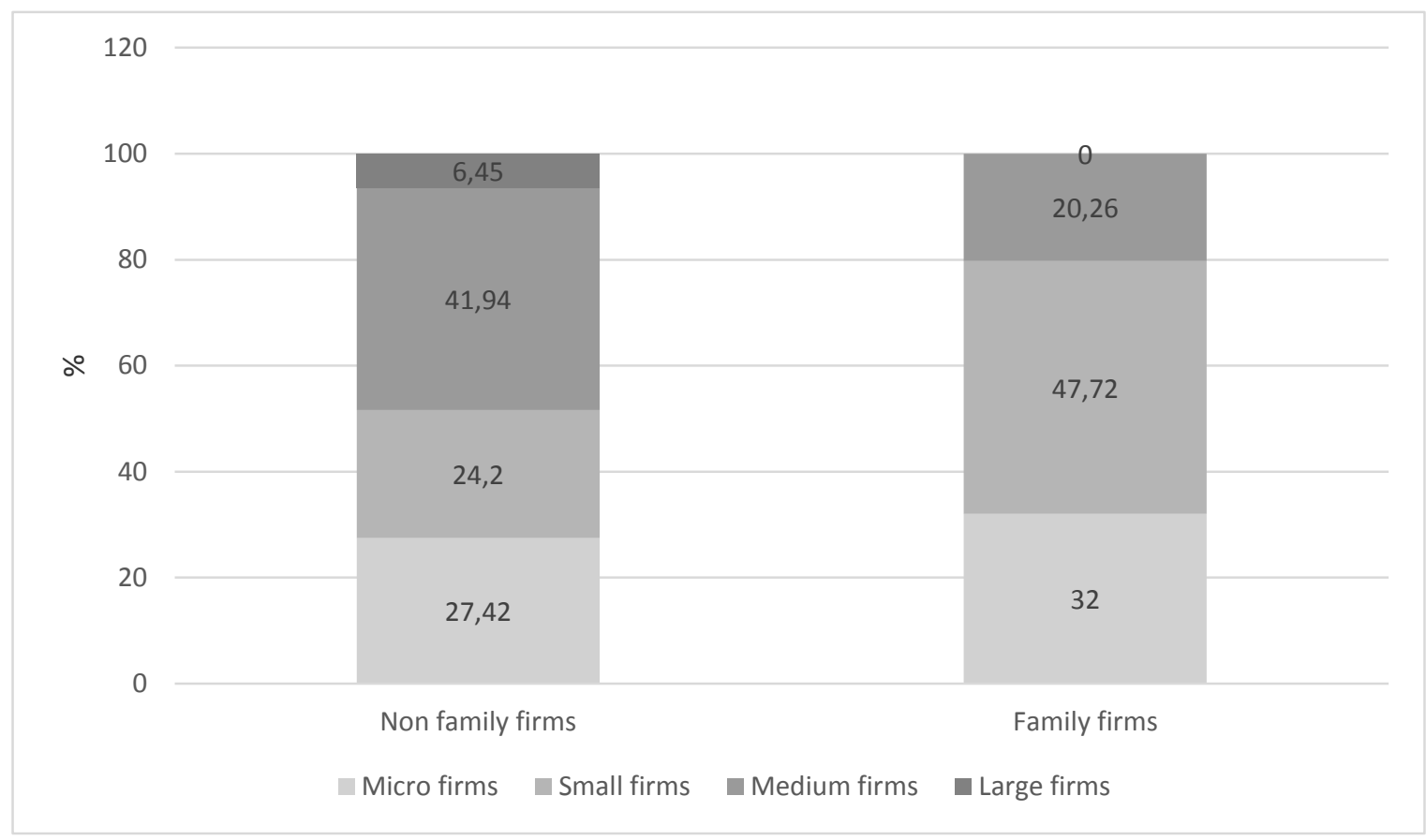

Figure 3. Nieumiędzynarodowione firmy rodzinne i nierodzinne w systematyzacji ze względu na wielkość (\%). Non-internationalized family and non-family firms by size (\%). Source: Own elaboration.

Based on the statistical analysis, it was concluded that family firms conduct business activity outside the domestic market much less frequently than non-family firms $\left(\chi^{2}=30.8\right.$; $\mathrm{p}<0.001)$. This result allowed for the positive verification of the $\mathrm{H} 1$ hypothesis, according to which family firms in Poland are less involved in international activity than non-family firms. The likelihood of this hypothesis was also verified using the Bayes Factor. It assumed a value of $\mathrm{BF}_{10}=1.71 \mathrm{e}+6$ for the variables under examination, which indicates very strong evidence in favor of the H1 hypothesis.

The most popular form of internationalization among the respondent firms was export and import (Figure 3). This form of internationalization is of similar interest to both family and non-family firms $\left(\chi^{2}=1.55 ; \mathrm{p}=0.213\right)$. Strategic alliances with foreign partners also attract similar interest $\left(\chi^{2}=0.26 ; p=0.61\right)$ from both family and non-family firms. Family firms, on the other hand, get involved in non-equity cooperation more frequently than non-family firms $\left(\chi^{2}=8.22 ; \mathrm{p}=0.004\right)$, whereas non-family firms establish their divisions abroad significantly more often than family firms $\left(\chi^{2}=8.22 ; \mathrm{p}=0.002\right)$. Interestingly, neither family nor non-family firms are generally interested in setting up a joint venture with a foreign investor. Among the respondents, only $2 \%$ of non-family firms declared being a shareholder in 
such an entity. In this case, no statistically significant differences between the two groups of firms exist $\left(\chi^{2}=0.718 ; p=3.97\right)$.

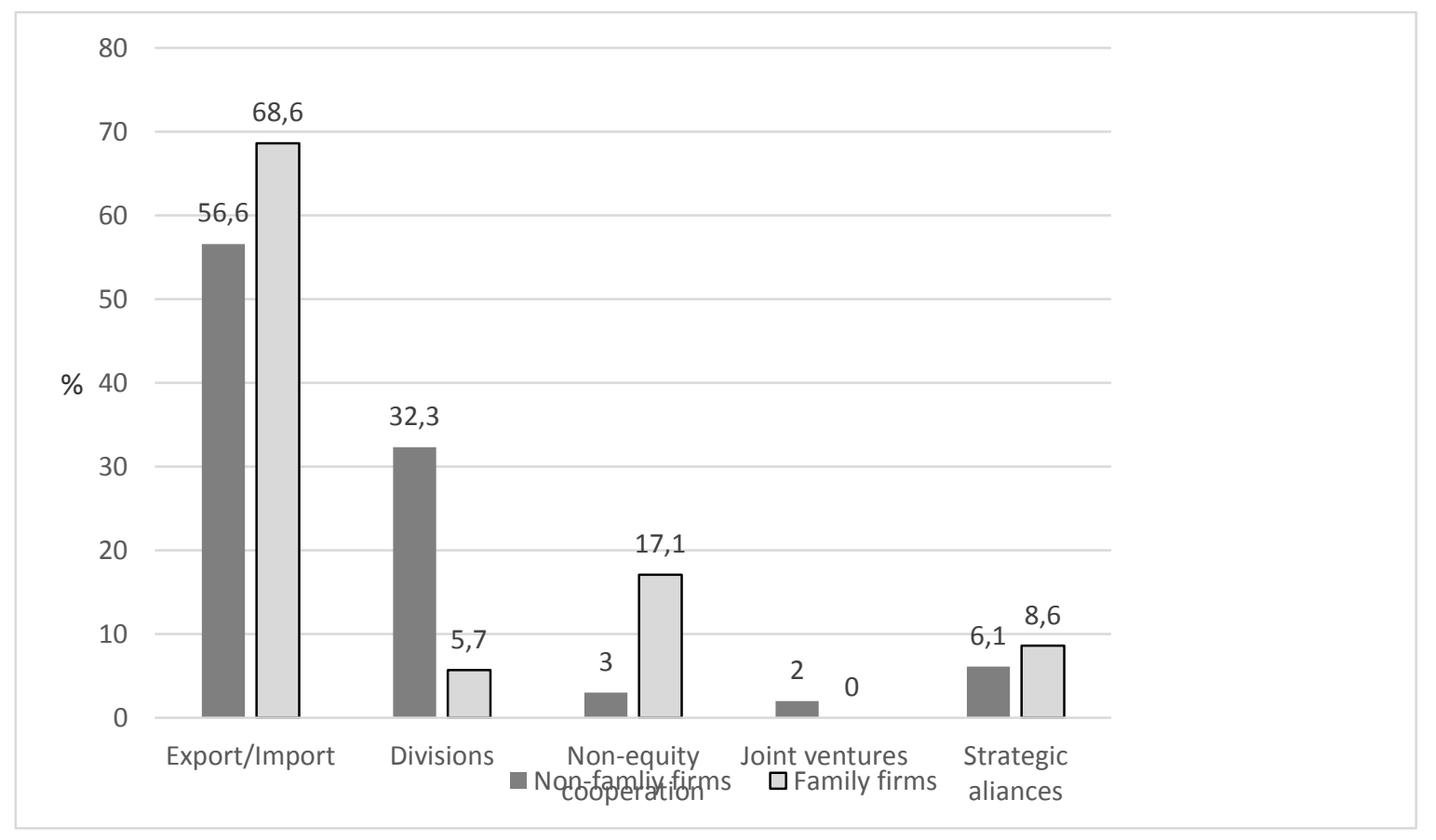

Figure 3. Forms of internationalization in family and non-family respondent forms (\%). Source: Own elaboration.

The statistically significant differences that were identified between family and non-family firms as regards the establishment of foreign divisions and the extent of their involvement in various forms of equity cooperation allow for the positive verification of the hypotheses $\mathrm{H} 2$ (Family firms are significantly less likely to establish divisions abroad than non-family firms) and H3 (Family firms are significantly more likely to engage in non-equity cooperation than non-family firms). The Bayes Factor $\mathrm{BF}_{10}$ proves high likelihood that these hypotheses are correct. In the case of the $\mathrm{H} 2$ hypothesis, the factor is $\mathrm{BF}_{10}=71.10$, while in the case of the $\mathrm{H} 3$ hypothesis, $\mathrm{BF}_{10}=6.59$. The value of the $\mathrm{BF}_{10}$ thus confirms very strong evidence in favor of the $\mathrm{H} 2$ hypothesis and substantial evidence in favor of the $\mathrm{H} 3$ hypothesis.

\section{Discussion}

The analysis of the results indicates that family firms conduct business activity outside the domestic market significantly less frequently than non-family firms. This finding seems to be fully justified taking into account that Polish family firms are relatively young. Most of them were established only after 1989, when the economic and political transformation took place in Poland. Therefore, most Polish family firms are only going through their first generation 
takeover. The founders of these firms, who often still manage them today, had to first learn how to run a firm in a market economy. Then, after Poland's accession to the European Union, they learned how to face intense competition. Many of these firms avoided external partners or shareholders for fear of losing control over their own business and, as a result, experienced capital shortages for years, walking the thin line between profits and losses. In such circumstances, it is difficult to expect them to become involved in international activity, which requires both knowledge and capital expenditure. In the case of Polish non-family firms, foreign expansion was easier because they were not afraid of losing control and did not restrict their sources of funding to their own resources and family capital.

The lower involvement of the respondent family and non-family firms in international activity may be also rooted in the attachment of the majority of these firms to tradition and familiar local markets (Mitter et al., 2014). Bearing in mind that foreign expansion is a high risk undertaking, the fact that family firms in principle avoid making high risk decisions (Casillas et al., 2010) may also have an impact on the results of the survey.

Forms of internationalization chosen by family firms when they decide to pursue international activity also point to their different attitude to risk than that of non-family firms. The results of the survey indicate that those Polish family firms that expand abroad prefer those forms of internationalization that are relatively low risk and do not pose a threat to their control over the ownership of the firm. The data gathered in the survey show that the form of internationalization most frequently adopted by Polish family firms is export and import. Generally, these firms are not interested in establishing joint ventures with foreign partners.

Compared to non-family enterprises, Polish family firms establish their divisions abroad significantly less frequently. On the other hand, they engage in non-equity cooperation much more often than non-family firms. Therefore, it can be inferred that the family firms that expand internationally limit the risk involved by choosing a form of internationalization. Thus, similarly to most family firms operating abroad, Polish family firms avoid high risk decisions that could result in a loss of control over the business.

However, the analysis of the forms of internationalization in the respondent firms clearly revealed that both family and non-family firms favor export and import, which is the most common form of internationalization. It seems possible, therefore, that, according to the Uppsala Model, some of the firms involved in export and import will progress to the subsequent stages of internationalization in the future. Over the next few years, the forms of internationalization of Polish family and non-family firms may, as a result, change. In the case of family firms, such a scenario seems highly likely because most Polish family firms have already gone through the first succession or are preparing for it, and successors are often willing to implement changes in the business (Fernandez, and Nieto, 2005). Moreover, they usually do not experience capital related problems as the generation of founders did (Mitter et al., 2014). 


\section{Conclusions}

Revealing the differences in the involvement of family and non-family firms in international expansion, the survey provides valuable information on the activity of Polish family firms in foreign markets as compared to non-family firms. As the issues related to the internationalization of family firms are under-researched in Poland (Leszczewska, and Zaniewska, 2013), it can be concluded that the results of the survey significantly enrich the knowledge in this area.

The differences identified between family and non-family firms in terms of their involvement in international activity are consistent with most studies comparing the two groups of entities. As Kontinen and Ojala (2010) point out in their literature review on the internationalization of family firms, the studies generally show that family firms are less internationalized than non-family firms.

The results also reinforce the findings of previous surveys showing that family involvement in business and family ownership affect the internationalization of family firms (Alayo et al., 2020; Arregle et al., 2012). In addition, they are in line with the conclusions of other studies, arguing that family firms focus their business primarily on local markets (Mitter et al., 2014).

Additionally, the study provides further support to the categorization of family and non-family firms as separate types of business entities. This division emerged several years ago and since then numerous studies confirm its validity. At present, some researchers even propose to extend this division (Kontinen, and Ojala, 2010).

\section{References}

1. Alayo, M., Iturralde, T., Maseda, A. and Aparicio, G. (2020). Mapping family firm internationalization research: bibliometric and literature review, Rev. Manag. Sci. https://doi.org/10.1007/s11846-020-00404-1.

2. Arregle, J.L, Naldi, L., Nordqvist, M., and Hitt, M.A. (2012). Internationalization of Family-Controlled Firms: A Study of the Effects of External Involvement in Governance. Entrepreneurship Theory And Practice, Vol. 1, pp. 1115-1143. doi: 10.1111/j.15406520.2012.00541.x.

3. Camisón, C., and Villar-López, A. (2010). Effect of Smes' International Experience on Foreign Intensity and Economic Performance: The Mediating Role of Internationally Exploitable Assets and Competitive Strategy. Journal of Small Business Management, Vol. 48(2), pp. 116-151. 
4. Carr, C., and Bateman, S. (2009). International strategy configurations of the world's top family firms: anotherfactor affecting performance. Manag. Int. Rev., Vol. 49(6), pp. 733-758. https://doi.org/10.1007/s11575-009-0018-3.

5. Casillas, J.C., Moreno, A.M., and Acedo, F.J. (2017). Internationalization of Family Businesses: a Theoretical Model Based on International Entrepreneurship Perspective. Global Management Journal, Vol. 2, pp. 18-35.

6. Domurat, A., and Białek, M. (2016). Dowodzenie hipotez za pomocą czynnika bayesowskiego (bayes factor): przykłady użycia w badaniach empirycznych. Decyzje, No. 26, pp. 109-141.

7. European Commission Recommendation of 6 May 2003 concerning the definition of micro, small and medium-sized enterprises. Document number C (2003) 1422, Text with EEA relevance, 2003/361/EC. Official Journal of the European Union, European Commission 2003.

8. Fernández, Z., and Nieto, M. (2006). Impact of ownership on the international involvement of SMEs. Journal of International Business Studies, Vol. 37(3), pp. 340-351. https://doi.org/10.1057/palgrave.jibs.8400196.

9. Fernandez, Z., and Nieto, M.J. (2005). Internationalization strategy of small and medium sized family businesses: Some influential factors. Family Business Review, Vol. 18(1), pp. 77-89. https://doi.org/10.1111/j.1741-6248.2005.00031.x.

10. Graves, C., and Thomas, J. (2004). Internationalisation of the family business: A longitudinal perspective. International Journal of Globalisation and Small Business, Vol. 1(1), pp. 7-27.

11. Kontinen, T., and Ojala, A. (2010). The internationalization of family businesses: A review of extant research. Journal of Family Business Strategy, 1(2), pp. 97-107. https://doi.org/10.1016/j.jfbs.2010.04.001.

12. Kraśnicka, T. (2017). Sukcesja i kondycja ekonomiczno-finansowa firm rodzinnych w Polsce i Czechach. Wyniki badań jakościowych. Zeszyty Naukowe Politechniki Ślaskiej, z. 108, no. 1983, pp. 203-214.

13. Larraza-Kintana, M., Wiseman, R.M., Gomez-Mejia, L.R., and Welbourne, T.M. (2007). Disentangling com-pensation and employment risks using the behavioral agency model, Strategic Management Journal, Vol. 28, pp. 1001-1019. doi: 10.1002/smj.624.

14. Lesáková, L. (2014). Small and medium enterprises in the new world of globalization. Forum Scientiae Oeconomia, Vol. 2(3), pp. 111-122.

15. Leszczewka, and K. Zaniewska, K. (2013). Motywy i formy internacjonalizacji firm rodzinnych, Przedsiębiorczość i Zarzadzanie, Vol. XIV, Issue 6, part I, pp. 261-271.

16. Mandl, I. (2008). Overview of Family Business Relevant Issues, Final Report. KMU Forschung Austria, Vienna: Austrian Institute for SME Research. 
17. Mitter, C., Duller, C., Feldbauer-Durstmüller, B., and Kraus, S. (2014). Internationalization of family firms: the effect of ownership and governance. Rev. Manag. Sci., Vol. 8, pp. 1-28. doi: 10.1007/s11846-012-0093-x.

18. Muñoz-Bullón, F., Sanchez-Bueno, M.J., \& De Massis, A. (2020). Combining Internal and External R\&D: The Effects on Innovation Performance in Family and Nonfamily Firms. Entrepreneurship Theory and Practice, 44(5), 996-1031. https://doi.org/10.1177/ 1042258719879674.

19. Pukall, T.J., and Calabrò, A. (2014). The Internationalization of Family Firms: A Critical Review and Integrative Model. Family Business Review, Vol. 27(2), pp. 103-125. doi: $10.1177 / 0894486513491423$.

20. Sciascia, S., Mazzola, P., Astrachan, J.H., and Pieper, T.M. (2012). The role of family ownership in international entrepreneurship: exploring nonlinear effects. Small Bus Econ, Vol. 38(1), pp. 15-31. https://doi.org/10.1007/s11187-010-9264-9.

21. Steinerowska-Streb, I. (2014). Bariery rozwoju polskich małych i średnich przedsiębiorstw zaangażowanych i niezaangażowanych w działalność międzynarodową. Studia Ekonomiczne Regionu Łódzkiego, Vol. 12, pp. 149-159.

22. Steinerowska-Streb, I., Bernais, J. (2016). Źródła pozyskiwania pracowników w polskich przedsiębiorstwach rodzinnych. Ekonomika i Organizacja Przedsiębiorstwa, Vol. 11, pp. 85-97.

23. Steinerowska-Streb, I. (2016). Wybrane determinanty zatrudniania pracowników w polskich przedsiębiorstwach rodzinnych. Ekonomika i Organizacja Przedsiębiorstwa, Vol. 3(794), pp. 68-78.

24. Steinerowska-Streb, I., and Wziątek-Staśko, A. (2019). Innovations in family firms. A study of owner-managers' knowledge development. Journal of Family Business Management, Vol. 10(3), pp. 247-264. https://doi.org/10.1108/JFBM-09-2019-0058. 